\title{
Comparison of acid blue 25 adsorption performance on natural and acid-thermal co-modified bentonite: Isotherm, kinetics and thermodynamics studies
}

\author{
Doğal ve asit-termal modifiye bentonit üzerine asit blue 25 adsorpsiyon \\ performansının karşılaştırılması: İzoterm, kinetik ve termodinamik \\ çalışmaları
}

\author{
Adnan ALDEMIR ${ }^{*}$ iD , Ali Rıza KUL ${ }^{2}$ iD \\ ${ }^{1}$ Chemical Engineering Department, Faculty of Engineering, Van Yüzüncü Yıl University, Van, Turkey. \\ adnanaldemir@yyu.edu.tr \\ ${ }^{2}$ Chemistry Department, Faculty of Science, Van Yüzüncü Yıl University, Van, Turkey. \\ alirızakul@yyu.edu.tr
}

\begin{abstract}
In the present study, natural bentonite and acid-thermal co-modified bentonite were utilized for Acid Blue 25 (AB25) removal. The adsorption experiments were executed at the temperature values of $298 \mathrm{~K}, 308 \mathrm{~K}$ and 318K. According to the results, Freundlich isotherm becomes more convenient model compared with Langmuir and Temkin model. Freundlich model coefficients rise when the temperature increases. Kinetic coefficients were calculated by pseudo first order (PFO) and pseudo second order (PSO) models. Coefficients of $R^{2}$ evaluated were higher than 0.99 with experimental and obtained $q_{e}$ values close to each other explained that this process fits PSO kinetic model. The concentration of AB25 elevates from 30 to $80 \mathrm{mg} / \mathrm{L}$ adsorption capacity onto natural, acid-thermal co-modified bentonite increases from 8.36 to $27.00 \mathrm{mg} / \mathrm{g}$ and 9.30 to $29.09 \mathrm{mg} / \mathrm{g}$ for $298 \mathrm{~K}$, respectively. Absolute values of free energy of AB25 onto natural and acid-thermal co-modified bentonite changes from $4.065 \mathrm{~kJ} / \mathrm{mol}$ to $8.586 \mathrm{~kJ} / \mathrm{mol}$ respectively. Enthalpy values of AB25 onto natural and acid-thermal comodified bentonite changes from $5.483 \mathrm{~kJ} / \mathrm{mol}$ to $11.249 \mathrm{~kJ} / \mathrm{mol}$ and entropy values of $A B 25$ on natural and acid-thermal co-modified bentonite changes from $4.759 \mathrm{~J} / \mathrm{mol} \mathrm{K}$ to $8.940 \mathrm{~J} / \mathrm{mol} \mathrm{K}$, respectively. It was also found that modified bentonite has higher adsorption capacity than natural bentonite.
\end{abstract}

Keywords: Acid blue 25, adsorption, Bentonite, Isotherm model, Kinetic coefficient, Thermodynamic parameter.

\section{Introduction}

Dyes are colored organic compounds, and their chemical structures are extensively used in several industry such as plastics, rubber, cosmetics, food processing, textile, paper, printing, dye manufacturing and leather tanning [1],[2]. Dye molecules are stable, complex, poorly soluble, toxic to organisms in receiving waters and prejudicial to photosynthetic activities. For that reason, the dyes removals in the industrial effluents are essential. There are several treatment technologies such as processes of ion exchange, oxidation, coagulation-flocculation, reverse osmosis and adsorption [3]. Adsorption processes have relatively

\section{Öz}

Bu çalış̧mada, Asit Blue 25 (AB25) giderimi için doğal bentonit ve asittermal modifiye edilmiş bentonit kullanıldı. Adsorpsiyon deneyleri $298 K, 308 K$ ve $318 K$ sicaklık değerlerinde gerçekleștirildi. Sonuçlara göre Freundlich izotermi, Langmuir ve Temkin modeline göre daha uygun bir model haline geldi. Freundlich model katsaylları sicakllk arttıkça yükseldiği görüldü. Kinetik katsayılar yalancı birinci derece (PFO) ve yalancl ikinci derece (PSO) modelleri ile hesaplandl. Değerlendirilen $R^{2}$ katsayıları 0.99'dan yüksekti ve birbirine yakın deneysel ve elde edilen qe değerleri bu sürecin PSO kinetik modeline uyduğu açıklandı. 30 ve $80 \mathrm{mg} / \mathrm{L}$ bașlangıç konsantrasyonun, doğal, asit-termal modifiye edilmis bentonit ile adsorpsiyon kapasitesinin $298 \mathrm{~K}$ için sırasiyla 8.36'dan $27.00 \mathrm{mg} / \mathrm{g}$ 'ye ve 9.30 'dan $29.09 \mathrm{mg} / \mathrm{g}$ 'ye yükseldiği gözlendi. AB25'in serbest enerjisinin doğal ve asit-termal modifiye edilmiş bentonite karşı mutlak değerleri, sırasıyla $4.065 \mathrm{~kJ} / \mathrm{mol}$ 'den $8.586 \mathrm{~kJ} / \mathrm{mol}^{\prime} e$ değiștiği belirlendi. AB25'in doğal ve asit-termal modifiye edilmis bentonit üzerindeki entalpi değerleri $5.483 \mathrm{~kJ} / \mathrm{mol}$ 'den $11.249 \mathrm{~kJ} / \mathrm{mol}^{\prime}$ e ve AB25'in doğal ve asit-termal modifiye edilmiş bentonit üzerindeki entropi değerleri $4.759 \mathrm{~J} / \mathrm{mol}$ K'den $8.940 \mathrm{~J} / \mathrm{mol}$ K.'ye değiştiği görüldü. Modifiye edilmiş bentonitin, doğal bentonitten daha yüksek adsorpsiyon kapasitesine sahip olduğu belirlendi.

Anahtar kelimeler: Acid blue 25, Adsorpsiyon, Bentonit, Izoterm model, Kinetic katsayı, Termodinamik parametre.

economical, flexible, simple design, comfort in operation and efficient removal of dyes with adsorbents [4],[5].

Performance of adsorption process is related with adsorbent materials and several adsorbents have been used for the dyes removal from wastewaters. For example, fly ash, clay minerals, resin, fruit peels, layered double hydroxides, the biological strawhave play a critical role in wastewater purification [6],[7]. A number of clays have several advantages and have high adsorption capacity, which is comparable to activated carbons, towards many groups of dyes [8]. In previous studies, adsorption of dyes using mostly bentonite or some other clay minerals which are demonstrate important dye removal performances while it is required to improve its adsorption capabilities for most effective adsorption process [9],[10].

\footnotetext{
${ }^{*}$ Corresponding author/Yazışılan Yazar
} 
Bentonite is one of the low cost and good performed for dye adsorption process clay mineral which is identified clearly in previously published works [11],[12].

Dyes are classified as natural and synthetic dyestuffs. Synthetic dyes are categorized: non-ionic (dispersed), cationic (basic) and anionic (direct, acid and reactive) [13],[14]. Acidic dyes have been commonly utilized for dyeing of leather, silk, polyamide, wool, as well as cosmetics, paper, food, and ink-jet printing. The main categories of acidic dyes are anthraquinone, azo dyes, triphenylmethane, azine, xanthene, nitrozo and nitro. Their removal from wastewater requires more care and attention because of resistant to degradation [15]. Acid Blue 25, an anthraquinone dye, is the most resistant to degradation and perseveres color for the long term in effluents. Because of their toxic effects, dyes have produced concerns relating to its use. In relation with it has been an important detrimental effects, it is essential to eliminate AB25 from aqueous solution [16]. Many adsorbents, for instance, activated carbon, unmodified and modified biosorbent species were investigated for adsorption of AB25, but efficiencies of most adsorbents were not very acceptable [17]. For dye adsorption, AB25 dye was selected because of its commercial importance and its applications availability in dying industry [18],[19].

The interference among the adsorbent and the adsorbate molecules is reported at the adsorption isotherms. A plot of adsorption isotherm associates with the quantity of substance adsorbed by the adsorbent molecules. The adsorbent nature changes with the amount of adsorbate and adsorbent affect the adsorption isotherm profile. Three different isotherm models were used for investigate the result. In this investigation, all mentioned ones are considered. Considering the Langmuir isotherm, the assumption was made that sorption is monolayer and all the active sites on surface of adsorbent are equal in energy. Freundlich isotherm clarifies the multilayer adsorption behavior. To investigate the adsorption mechanism PFO and PSO kinetic equation constants are calculated [20].

The aim of this research is comparison of adsorption performance of the natural bentonite and acid-thermal comodified bentonite which is low cost and abundant adsorbent for AB25 including isotherm, kinetic, thermodynamic studies.

\section{Materials and methods}

\subsection{Adsorbent (Natural and modified bentonite)}

The natural bentonite (Ca-Bentonite) obtained from Kütahya region in Turkey was used. The formula of bentonite is $\mathrm{Al}_{2} \mathrm{H}_{2} \mathrm{O}_{12} \mathrm{Si}_{4}$ and molecular weight $360.31 \mathrm{~g} / \mathrm{mol}$. The activation process is applied to make changes in the surface area and the physicochemical properties. A reactor made of pyrex glass, with a condenser, was used. $250 \mathrm{~mL}$ of $5 \mathrm{~N} \mathrm{HCl}$ solution was slowly added to $50 \mathrm{~g}$ of bentonite which had been put into the reactor and allowed to stand for 3 hours under continuous stirring at boiling temperature about $105^{\circ} \mathrm{C}$. The washing 15 times with distilled water was repeated in order to eliminate acid residues after products of reaction were filtered. At the end of each wash, the presence of Cl- ions was checked with the silver acetate solution. Then, the solution was centrifuged at $4500 \mathrm{rpm}$ for 5 minutes. After final wash, the sample was centrifuged and it was incubated at $60^{\circ} \mathrm{C}$ for 48 hours. The bentonite sample was milled because of crushing lumps formed during drying and stored in a desiccator after passing through 235 mesh sieves $(61.75 \mu \mathrm{m})$. After acid activation, bentonite samples were heated at $600{ }^{\circ} \mathrm{C}$ for 24 hours and then stored by passing through a 235 mesh sieve $(61.75 \mu \mathrm{m})$ for thermal activation.

\subsection{Adsorbate (Acid Blue 25)}

$\mathrm{AB} 25$ was used as the adsorbate in the current research. The formula of $\mathrm{AB} 25$ is $\mathrm{C}_{20} \mathrm{H}_{13} \mathrm{~N}_{2} \mathrm{NaO}_{5} \mathrm{~S}$ and molecular weight $416.38 \mathrm{~g} / \mathrm{mol}$. This dye was taken from Merck Chemicals.

\subsection{Batch adsorption experiments}

Different dye concentrations (30-80 mg/L) of AB25 were prepared and $1 \mathrm{~g}$ bentonite was treated with $500 \mathrm{~mL}$ of dye solution. AB25 concentration in solution was determined for $240 \mathrm{~min}$. The same operations were made for natural, and acidthermal co-modified bentonite at 298,308 and $318 \mathrm{~K}$ temperatures. To determine the effects of $\mathrm{pH}$ values and initial concentrations, batch experiments were carried out in triplicate. Concentration of AB25 in solution at $602 \mathrm{~nm}$ absorbance wavelength was evaluated by the UV/VIS spectrophotometer (PG Instruments Ltd, T80 model). The adsorbent capacity towards dye was analyzed as:

$$
\mathrm{q}_{\mathrm{e}}=\left(\mathrm{C}_{0}-\mathrm{C}_{\mathrm{e}}\right) \mathrm{V} / \mathrm{m}
$$

Where $V$ was the solution volume (L), $C_{0}$ and $C_{e}$ were initial and equilibrium concentration of dye ( $\mathrm{mg} / \mathrm{L})$ and $m$ was adsorbent mass (g).

Dye concentration, temperature and initial $p H$ effects on AB25 adsorption were investigated. Effect of concentration was studied by natural and modified bentonite to a range of 30-80 $\mathrm{mg} / \mathrm{L}$ AB25. Temperature effects on the equilibrium of AB25 adsorption on the natural and modified bentonite was carried out 298, 308 and $318 \mathrm{~K}$. Effect of $p H$ was determined with adjusting the $p H$ of solution with $0.1 \mathrm{~mol} / \mathrm{L} \mathrm{HCl}$ and $0.1 \mathrm{~mol} / \mathrm{L}$ $\mathrm{NaOH}$ solutions. An investigation of $p H$ on adsorption of $\mathrm{AB} 25$ was carried out at $p H$ range of $2-12$ for $2 \mathrm{~h}$. $p H$ of the solutions containing adsorbents were determined by adding in two Erlenmeyer flask $1 \mathrm{~g}$ of natural and modified bentonite in $50 \mathrm{~mL}$ distilled water, stirred for $24 \mathrm{~h}$, filtered, and final $p H$ measured. $p H$ of zero point charge $\left(p H_{Z P C}\right)$ was determined as described in [21].

\section{Results and discussion}

\subsection{Characterization of adsorbent}

Chemical constituent of bentonite sample was analyzed by XRay Fluorescence (XRF). Chemical composition of bentonite was observed as follows: $71.60 \mathrm{wt} \% \mathrm{SiO}_{2}, 2.79$ wt.\% $\mathrm{MgO}$, 13.15 wt. $\% \mathrm{Al}_{2} \mathrm{O}_{3}, 0.36$ wt. $\% \mathrm{~K}_{2} \mathrm{O}, 2.23$ wt.\% $\mathrm{CaO}, 0.66$ wt.\% $\mathrm{Fe}_{2} \mathrm{O}_{3}, 0.26$ wt.\%, $\mathrm{Na}_{2} \mathrm{O}, 0.07$ wt. $\% \mathrm{TiO}_{2}$ and 8.45 wt.\% loss of ignition. The bentonite samples were characterized with Brunauer Emmett Teller (BET), volumetric analyzer, respectively. Details of the adsorption events based on characterization results are given in [22]. BET analysis of bentonite samples was carried out (Quantachrome NOVA2200 model). The surface areas of bentonite samples are higher than other clays which given in [2].

\subsection{Effect of time and initial dye concentration}

Time is one of the critical physical parameters used economically for the plan and operating wastewater treatment plants. In Figure 1 and 2, the AB25 removal from the solutions is rapid at the initial period and that the efficiency at the final period that near the reach of the equilibrium state. In the beginning, the surface of the adsorption process is large, so the 
adsorption to this surface is fast and the equilibrium time for AB25 adsorption was determined to be $2 \mathrm{~h}$.

Figure 1 and 2 demonstrates that the rise at the initial concentration of AB25 caused the increment in adsorption capacity. As the initial concentration rises from 30 to $80 \mathrm{mg} / \mathrm{L}$ adsorption capacity onto natural and acid-thermal co-modified bentonite from 8.36 to $27.00 \mathrm{mg} / \mathrm{g}$ and 9.30 to $29.09 \mathrm{mg} / \mathrm{g}$ for $298 \mathrm{~K}$, respectively. These data show that AB25 concentration have critical role in the adsorption capacity and that provides a driving force to the interaction between adsorbent and adsorbate. Based on results maximum adsorption capacity was obtained with acid-thermal co-modified bentonite. Previously reported results from various researchers were available for Acid Blue adsorption on different adsorbents and biosorbents such as: cucurbituril, activated carbon, modified silica, olive pomace boiler ash, sawdust, shrimp shell, chitosan [20],[23], [24]. The adsorption capacities obtained in this work were higher than others in previous studies. The results show that bentonite may be an inexpensive material in accordance with other adsorbents for dye removal.

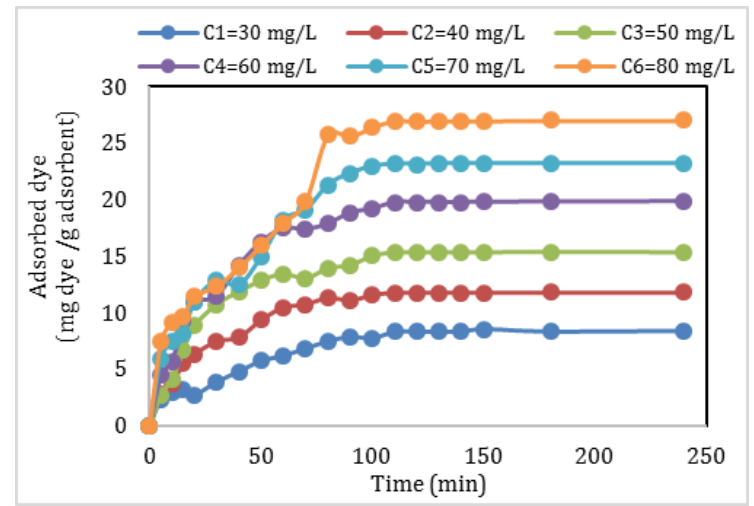

Figure 1. Effect of concentration on dye adsorption with natural bentonite ( $\mathrm{pH} 7.0,298 \mathrm{~K}, 1 \mathrm{~g}$ adsorbent/L)

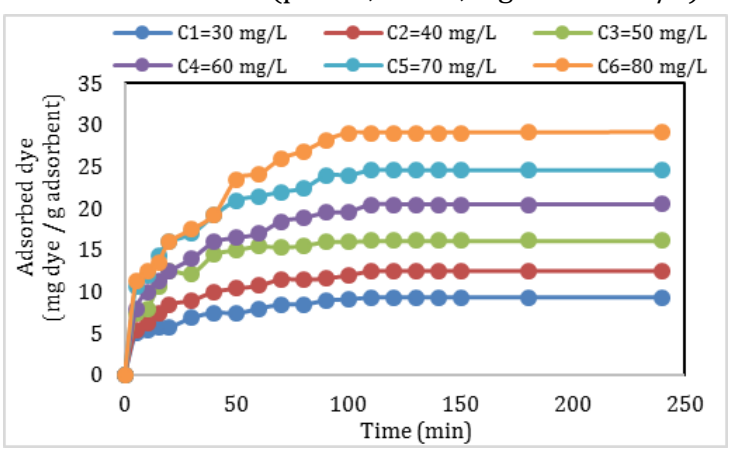

Figure 2. Effect of concentration on dye adsorption with modified bentonite ( $\mathrm{pH}$ 7.0, $298 \mathrm{~K}, 1 \mathrm{~g}$ adsorbent/L)

\subsection{Effect of solution $\mathbf{p H}$}

The value of $p H$ can influence the dissociation of sites and the solution chemistry of AB25, particularly degree of ionization. Therefore, AB25 adsorption on the natural and acid-thermal co-modified bentonite was studied at $298 \mathrm{~K}$ in the using AB25 concentration of $80 \mathrm{mg} / \mathrm{L}$ and bentonite of $1 \mathrm{~g} / \mathrm{L}$. The maximum adsorption was observed at an acidic conditions $(p H 2)$ and adsorption decreased slowly with increase in $p H$ values (Figure 3). At a very low $p H$, concentration of $\mathrm{H}^{+}$in bulk solution would be high and carboxyl, hydroxyl, and amino groups would be protonated, thus enhancing electrostatic attraction between adsorbent and adsorbate [5]. A reduction in the number of positively charged adsorbent surfaces would be observed while $p H$ value increased. Similar results were determined for AB25 adsorption by activated carbon and sepiolite [20],[25]. $p H_{Z P C}$ values of natural and modified bentonite were obtained 8.95 and 8.55 , respectively (Figure 4). These results support the AB25 adsorption is favoured at $p H<$ $p H_{Z P C}$ because of the surface becomes positively charge.

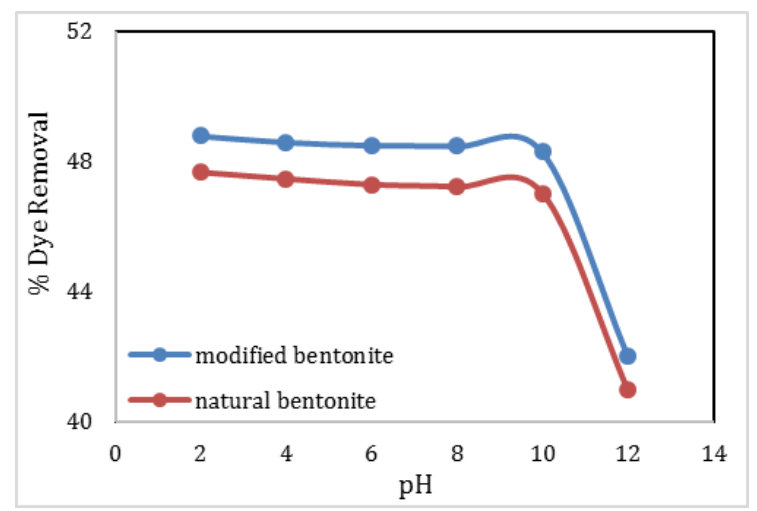

Figure 3. Effect of $\mathrm{pH}$ on natural and modified bentonite (80 mg/L dye conc., $298 \mathrm{~K}, 1 \mathrm{~g}$ adsorbent/L)

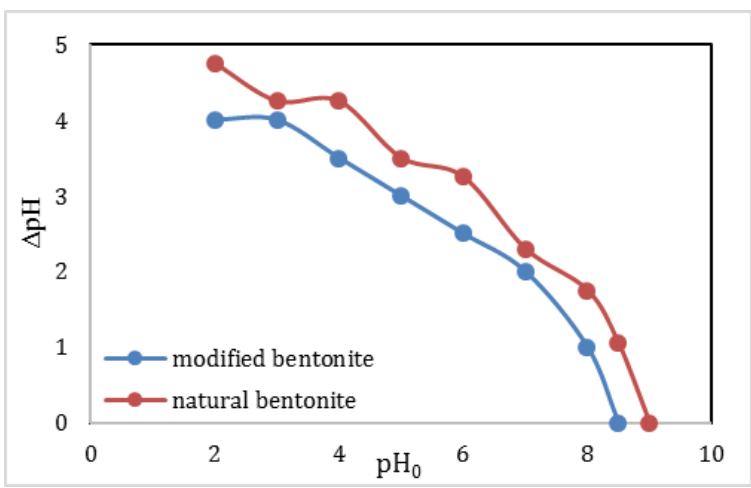

Figure 4. pHzPc plot of natural and modified bentonite.

\subsection{Adsorption isotherm model studies}

Many models are used to identify the dyes adsorption on solid surfaces. For the interaction between adsorbate molecules and adsorbent surface investigations, Freundlich, Langmuir and Temkin well-established models were chosen to endeavor to simplify the interactions between dye and adsorbent in the study. Three models were applicable for the descriptions of the experimental results obtained at three different temperatures.

Langmuir isotherm is given in Eq. (2);

$$
q_{e}=\left(q_{m} K_{L} C_{e}\right) /\left(1+K_{L} C_{e}\right)
$$

Where $q_{m}$ denotes maximum capacity of adsorption (mg/g), $C_{e}$ represents equilibrium concentration $(\mathrm{mg} / \mathrm{L}), K_{L}$ is a Langmuir constant (L/g). A linear form of Eq. 2 was obtained when $C_{e} / q_{e}$ versus $C_{e}$ was plotted. $q_{m}$ and $K_{L}$ values can be determined from the plot (Table 1).

Freundlich isotherm equation is mainly reported in Eq. (3);

$$
q_{e}=K_{F} C e^{1 / n}
$$

Where $K_{F}$ is a Freundlich constant (L/g), $1 / n$ is an empirical parameter connected to adsorption intensity. A linear form of Eq. 3 was obtained when the natural logarithm of $q_{e}$ versus $C e$ was plotted. Slope and intercept of line show $n$ and $K_{F}$ values, respectively (Table 1 ). 
Table 1. Isotherm model parameters of AB 25 adsorption on bentonite.

\begin{tabular}{|c|c|c|c|c|c|c|c|}
\hline \multirow[t]{2}{*}{ Isotherm } & \multirow{2}{*}{$\frac{\text { Temp }}{\mathrm{K}}$} & \multirow{2}{*}{$\frac{\text { Natural Bentonite }}{\mathrm{K}_{\mathrm{L}}(\mathrm{L} / \mathrm{g})}$} & \multicolumn{5}{|c|}{ Modified Bentonite } \\
\hline & & & $\mathrm{q}_{\mathrm{m}}(\mathrm{mg} / \mathrm{g})$ & $\mathrm{R}^{2}$ & $\mathrm{~K}_{\mathrm{L}}(\mathrm{L} / \mathrm{g})$ & $\mathrm{q}_{\mathrm{m}}(\mathrm{mg} / \mathrm{g})$ & $\mathrm{R}^{2}$ \\
\hline \multirow{3}{*}{ Langmuir } & 298 & 0.023 & 19.608 & 0.828 & 0.026 & 23.231 & 0.877 \\
\hline & 308 & 0.031 & 16.887 & 0.851 & 0.029 & 21.256 & 0.894 \\
\hline & 318 & 0.033 & 12.422 & 0.857 & 0.039 & 18.282 & 0.899 \\
\hline \multirow{4}{*}{ Freundlich } & $\mathrm{K}$ & $\mathrm{K}_{\mathrm{F}}(\mathrm{L} / \mathrm{g})$ & $1 / \mathrm{n}$ & $\mathrm{R}^{2}$ & $\mathrm{~K}_{\mathrm{F}}(\mathrm{L} / \mathrm{g})$ & $1 / \mathrm{n}$ & $\mathrm{R}^{2}$ \\
\hline & 298 & 0.081 & 1.789 & 0.953 & 0.127 & 1.725 & 0.987 \\
\hline & 308 & 0.029 & 2.192 & 0.974 & 0.169 & 1.726 & 0.992 \\
\hline & 318 & 0.029 & 2.259 & 0.978 & 0.129 & 1.726 & 0.996 \\
\hline \multirow{4}{*}{ Temkin } & $\mathrm{K}$ & $\mathrm{K}_{\mathrm{T}}(\mathrm{L} / \mathrm{g})$ & B & $\mathrm{R}^{2}$ & $\mathrm{~K}_{\mathrm{T}}(\mathrm{L} / \mathrm{g})$ & $\mathrm{B}$ & $\mathrm{R}^{2}$ \\
\hline & 298 & 0.045 & 28.248 & 0.857 & 0.063 & 28.647 & 0.859 \\
\hline & 308 & 0.041 & 35.678 & 0.917 & 0.085 & 30.559 & 0.907 \\
\hline & 318 & 0.045 & 37.353 & 0.915 & 0.099 & 36.427 & 0.903 \\
\hline
\end{tabular}

Temkin isotherm is expressed with Eq. (4);

$$
q_{e}=B \ln \left(K_{T} C_{e}\right)
$$

where $K_{T}$ represents binding constant corresponding to the maximum binding energy, $B$ illustrates constant related to heat of adsorption, $q_{e}$ denotes adsorption capacity obtained experimentally (mg/g), $C_{e}$ stands equilibrium $\mathrm{AB} 25$ concentration $(\mathrm{mg} / \mathrm{L})$ :

$$
B=R T / b_{T}
$$

where $1 / b_{T}$ symbolizes adsorption potential; $R$ means gas constant (8.314 J/kmol); and $T$ is temperature in Kelvin (K). B and $K_{T}$ values for different temperatures are given in Table 1.

Concerning coefficients determined Freundlich model is more fitting than other Langmuir and Temkin models. It is noted that $K_{F}$ and n values elevate as the temperature rises, as well as, adsorption is approving at higher temperature. $\mathrm{R}^{2}$ values of three isotherm models are high, but $\mathrm{R}^{2}$ values of the Freundlich model are higher than other model values for two types of bentonite. Previously reported results from various researchers were available for AB25 adsorption on different adsorbents and biosorbents such as; rubber leaf powder, activated carbon, diatomite, sepiolite, lychee peel, cempedak peel, soya bean waste, tarap peel, water lettuce [26].

\subsection{Adsorption thermodynamics}

Thermodynamic parameters are significant to detect heat alteration in the adsorption process for dye onto bentonite. These parameters are calculated by the equations given below:

$$
\begin{gathered}
K_{c}=C_{A d s} / C_{e} \\
\Delta G^{\circ}=-R T \ln K_{C} \\
\Delta G^{\circ}=\Delta H^{\circ}-T \Delta S^{\circ} \\
\ln K_{C}=\left(\Delta S^{\circ} / R\right)-\left(\Delta H^{\circ} / R T\right)
\end{gathered}
$$

Where, $K_{c}$ is equilibrium constant, $C_{A d s}$ represents dye amount adsorbed $\mathrm{mg}$ on bentonite per litter of the solution at equilibrium, the adsorbent of adsorbent per unit litter of solution $(\mathrm{mg} / \mathrm{L}) . \Delta H^{\circ}(\mathrm{kJ} / \mathrm{mol})$ and $\Delta S^{\circ}(\mathrm{J} / \mathrm{mol} . \mathrm{K})$ parameters are analyzed from slope and intercept of line ploted logarithm of $K_{c}$ with respect to $1 / T$. These parameters were illustrated in Table 3 .

Thermodynamic parameters of AB25 adsorption onto acidthermal co-modified bentonite are higher than natural bentonite and the parameters which obtained with natural bentonite were found to be the lowest values. The absolute values of free energy of AB25 onto natural and acid-thermal co-modified bentonite changes from $4.0647 \mathrm{~kJ} / \mathrm{mol}$ to $8.5855 \mathrm{~kJ} / \mathrm{mol}$, respectively. Enthalpy values of AB25 onto natural and acid-thermal co-modified bentonite changes from $5.4829 \mathrm{~kJ} / \mathrm{mol}$ to $11.2496 \mathrm{~kJ} / \mathrm{mol}$ and entropy values of AB25 on natural and acid-thermal co-modified bentonite changes from $4.7589 \mathrm{~J} / \mathrm{mol} . \mathrm{K}$ to $8.9400 \mathrm{~J} / \mathrm{mol} . \mathrm{K}$, respectively. $\Delta G^{\circ}$ values alter between 0 and $-30 \mathrm{~kJ} / \mathrm{mol}$ indicates that the adsorption is physisorption and absolute values of $\Delta G^{\circ}$ decrease as temperature rises showing that this separation process is constructive at low temperatures. The positive values of $\Delta H^{\circ}$ and $\Delta S^{\circ}$ shows that process is endothermic and high affinity of bentonite for AB25, respectively [20].

Table 2. Adsorption capacity of AB25 on various adsorbents.

\begin{tabular}{ccc}
\hline Adsorbent & $\mathrm{q}_{\mathrm{m}}(\mathrm{mg} / \mathrm{g})$ & References \\
\hline Baggase pith & 17.5 & {$[27]$} \\
Shorea dasyphylla sawdust & 24.4 & {$[28]$} \\
Peat & 14.4 & {$[29]$} \\
Aspergillus niger & 13.8 & {$[30]$} \\
Bentonite & 8.5 & {$[31]$} \\
Modified silica & 45.8 & {$[32]$} \\
Rubber leaf powder & 28.1 & {$[33]$} \\
Sawdust walnut & 36.9 & {$[34]$} \\
Sawdust cherry & 31.9 & {$[34]$} \\
Sawdust oak & 27.8 & {$[34]$} \\
Sawdust pitch pine & 26.2 & {$[34]$} \\
Natural bentonite & 27.0 & This work \\
Modified bentonite & 29.1 & This work \\
\hline
\end{tabular}

Table 3. Thermodynamic parameters of AB25 adsorption on natural and modified bentonite

\begin{tabular}{lccccc}
\hline Adsorbent & $\begin{array}{c}\text { Temp } \\
(\mathrm{K})\end{array}$ & $\begin{array}{c}\Delta \mathrm{G}^{\circ} \\
(\mathrm{kJ} / \mathrm{mol})\end{array}$ & $\begin{array}{c}\Delta \mathrm{H}^{\circ} \\
(\mathrm{kJ} / \mathrm{mol})\end{array}$ & $\begin{array}{c}\Delta \mathrm{S}^{\circ} \\
(\mathrm{J} / \mathrm{mol} . \mathrm{K})\end{array}$ & $\mathrm{R}^{2}$ \\
\hline Natural & 298 & -4.066 & & & \\
Bentonite & 308 & -4.017 & 5.483 & 4.759 & 0.986 \\
& 318 & -3.969 & & & \\
\hline Modified & 298 & -8.586 & & & \\
Bentonite & 308 & -8.496 & 11.249 & 8.940 & 0.997 \\
& 318 & -8.407 & & & \\
\hline
\end{tabular}

\subsection{Adsorption kinetic studies}

Kinetic models have been applied for checking experimental results of AB25 adsorption onto bentonite. The adsorption kinetics is important to choose the best test circumstances for adsorption process with the batch technique. The useful kinetic parameters for estimate of adsorption rate, provides vital 
knowledge. Kinetics of AB25 adsorption were calculated using PFO and PSO kinetic models. The well-suited model has been chosen depending on the linear regression coefficient of correlation coefficients $\mathrm{R}^{2}$ values. These models have been investigated according to experimental data at varied temperatures and initial AB25 concentrations.

Lagergren's kinetics equation can be the first for characterization of liquid-solid adsorption systems depending on solid capacity [23]. PFO linear model is given as:

$$
\ln \left(q_{e}-q_{t}\right)=\ln q_{e}-k_{1} t
$$

where $k_{1}\left(\mathrm{~min}^{-1}\right)$ is constant of PFO model and $q_{t}(\mathrm{mg} / \mathrm{g})$ is adsorption capacity at time $t$. To achieve constants of this model, plot of $\ln \left(q_{e}-q_{t}\right)$ against $t$ is drawn. PFO kinetic plots for adsorption of AB25 onto natural and acid-thermal comodified bentonite at various concentrations are given in Figure 5 and Figure 6, respectively.

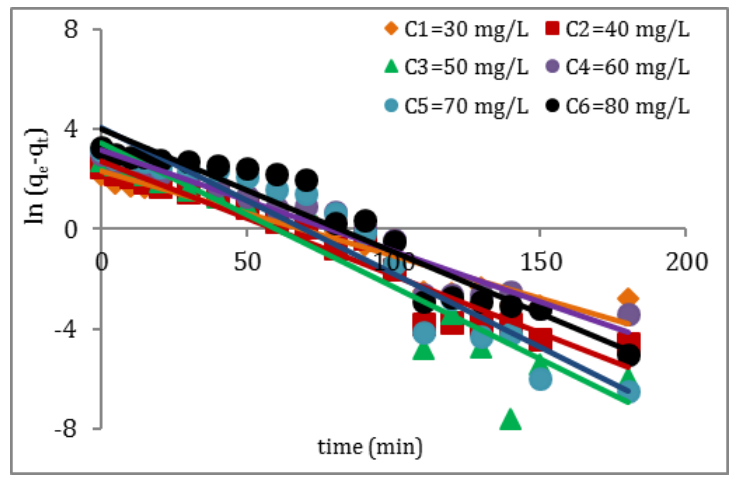

Figure 5. PFO plots for the adsorption of AB25 on natural bentonite at $298 \mathrm{~K}$.

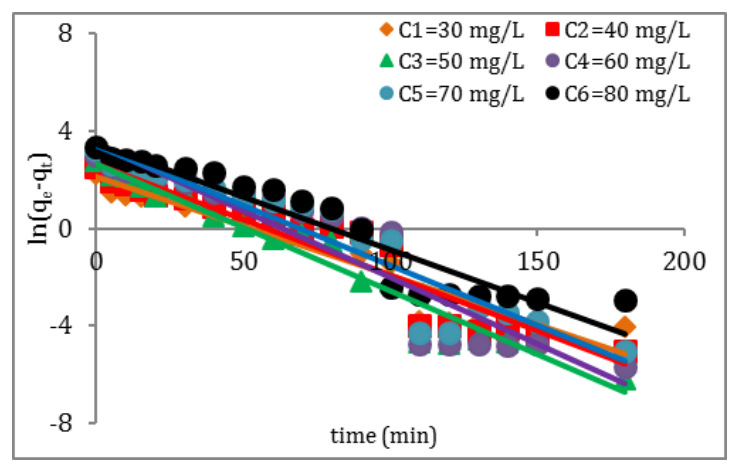

Figure 6. PFO plots for the adsorption of AB25 on modified bentonite at $298 \mathrm{~K}$.

Linear form of PSO model based on adsorption capacity is written below:

$$
t / q_{t}=1 /\left(k_{2} q_{e}^{2}\right)+\left(t / q_{e}\right)
$$

where $k_{2}$ represents rate of adsorption (g/mg.min) and $q_{t}$ is the amount of dye adsorbed at any time $(\mathrm{mg} / \mathrm{g})$. Values of $k_{2}$ and $q_{e}$ were identified from Eq. 11. The plots of PSO kinetic for adsorption of AB25 onto natural and acid-thermal co-modified bentonite at various concentrations are given in Figure 7 and Figure 8, respectively.

PFO and PSO model parameters of AB25 adsorption on natural and acid-thermal co-modified bentonite are given Table 4 and Table 5, respectively. $\mathrm{R}^{2}$ coefficients are higher than 0.99 with experimental and analyzed $q_{e}$ values close to each other explained that this process fits the PSO kinetic model.
Experimental and analyzed $q_{e}$ values of acid-thermal comodified bentonite are higher than natural bentonite values and calculated $q_{e}$ values of $318 \mathrm{~K}$ are higher than $298 \mathrm{~K}$ and $308 \mathrm{~K}$ values for two types of bentonite. According to these tables, it is obvious that $q_{e}$ values increases with increasing concentration of AB25. The kinetic constants are found closer to both temperatures and concentrations for PSO model. This result exhibited that $\mathrm{AB} 25$ adsorption kinetics on bentonite results from the PSO and suggested that the step of rate-limiting can be the dye chemisorption [23]. For numerous adsorption systems, adsorption kinetic data are better represented by PSO model with higher values of $\mathrm{R}^{2}$ than other kinetic models [1].

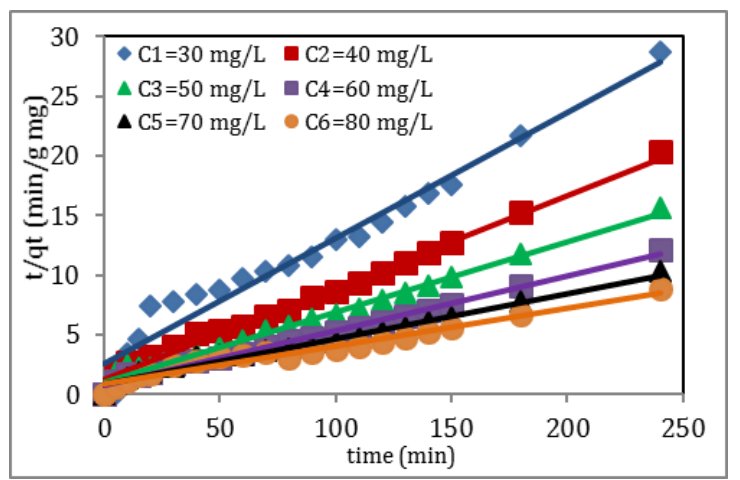

Figure 7. PSO plots for the adsorption of AB25 on natural bentonite at $298 \mathrm{~K}$.

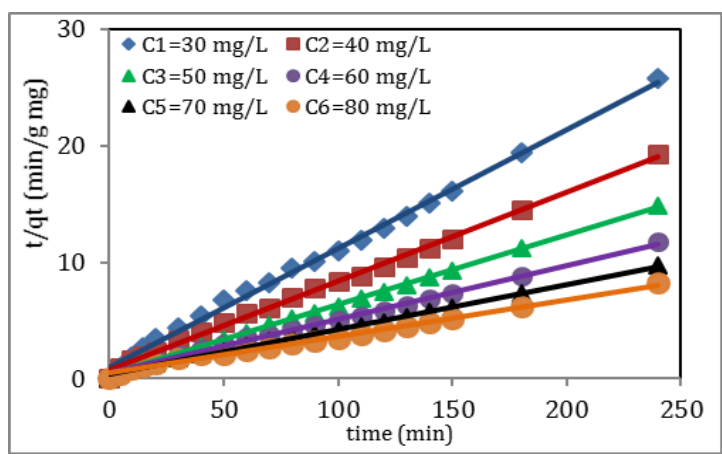

Figure 8. PSO plots for the adsorption of AB25 on modified bentonite at $298 \mathrm{~K}$.

\section{Conclusion}

AB25 adsorption on the natural, thermal modified and acid modified bentonite was examined at various experimental conditions. The current data display that adsorption of AB25 elevates with initial concentration, contact time and temperatures for natural and modified bentonites. As the AB25 concentration elevates from 30 to $80 \mathrm{mg} / \mathrm{L}$ dye adsorption capacity onto natural and acid-thermal co-modified bentonite increases from 8.36 to $27.00 \mathrm{mg} / \mathrm{g}$ and 9.30 to $29.09 \mathrm{mg} / \mathrm{g}$ for $298 \mathrm{~K}$, respectively. The maximum adsorption rate was obtained with modified bentonite and equilibrium time was determined at $120 \mathrm{~min}$ for two bentonite types.

Isotherm studies demonstrate that the Freundlich model shows more suitable for AB25 adsorption on bentonite than the Langmuir and Temkin models. It is noted that the values of $K_{F}$ and $\mathrm{n}$ raise as temperature increments, and also indicated that adsorption is approving at higher temperature. $\mathrm{R}^{2}$ values of two isotherm models are high, but $\mathrm{R}^{2}$ values of the Freundlich model are higher than other model values for two types of bentonite. 
Table 4. PFO kinetic model parameters of AB25 adsorption on bentonite.

\begin{tabular}{|c|c|c|c|c|c|c|c|c|}
\hline & $\begin{array}{c}\text { Temp. } \\
(\mathrm{K})\end{array}$ & $\begin{array}{l}\text { PFO kinetic } \\
\text { coefficients }\end{array}$ & $\begin{array}{c}30 \\
(\mathrm{mg} / \mathrm{L})\end{array}$ & $\begin{array}{c}40 \\
(\mathrm{mg} / \mathrm{L})\end{array}$ & $\begin{array}{c}50 \\
(\mathrm{mg} / \mathrm{L}) \\
\end{array}$ & $\begin{array}{c}60 \\
(\mathrm{mg} / \mathrm{L})\end{array}$ & $\begin{array}{c}70 \\
(\mathrm{mg} / \mathrm{L}) \\
\end{array}$ & $\begin{array}{c}80 \\
(\mathrm{mg} / \mathrm{L})\end{array}$ \\
\hline \multirow{16}{*}{ NB } & \multirow{4}{*}{298} & $\mathrm{k}_{1}\left(\min ^{-1}\right)$ & 0.0340 & 0.0458 & 0.0576 & 0.0406 & 0.0587 & 0.0491 \\
\hline & & $\mathrm{q}_{\mathrm{e} \exp }(\mathrm{mg} / \mathrm{g})$ & 8.362 & 11.757 & 15.311 & 19.812 & 23.158 & 27.000 \\
\hline & & $\mathrm{q}_{\mathrm{e} \mathrm{cal}}(\mathrm{mg} / \mathrm{g})$ & 10.172 & 15.132 & 20.350 & 23.441 & 57.905 & 53.506 \\
\hline & & $\mathrm{R}^{2}$ & 0.9251 & 0.9439 & 0.8755 & 0.9444 & 0.9231 & 0.9270 \\
\hline & \multirow{4}{*}{308} & $\mathrm{k}_{1}\left(\min ^{-1}\right)$ & 0.0327 & 0.0462 & 0.0474 & 0.0369 & 0.0326 & 0.0414 \\
\hline & & $\mathrm{q}_{\mathrm{e} \exp }(\mathrm{mg} / \mathrm{g})$ & 8.594 & 11.840 & 15.996 & 20.472 & 24.446 & 28.614 \\
\hline & & $\mathrm{q}_{\mathrm{e} \mathrm{cal}}(\mathrm{mg} / \mathrm{g})$ & 7.900 & 16.420 & 22.856 & 16.580 & 30.753 & 45.029 \\
\hline & & $\mathrm{R}^{2}$ & 0.9480 & 0.9549 & 0.9437 & 0.9383 & 0.9167 & 0.8953 \\
\hline & \multirow{4}{*}{318} & $\mathrm{k}_{1}\left(\min ^{-1}\right)$ & 0.0411 & 0.0523 & 0.0508 & 0.0509 & 0.0415 & 0.0512 \\
\hline & & $\mathrm{q}_{\mathrm{e} \exp }(\mathrm{mg} / \mathrm{g})$ & 8.740 & 12.452 & 16.301 & 20.599 & 24.778 & 29.462 \\
\hline & & $\mathrm{q}_{\mathrm{e} \mathrm{cal}}(\mathrm{mg} / \mathrm{g})$ & 8.982 & 21.257 & 20.139 & 34.069 & 38.432 & 56.860 \\
\hline & & $\mathrm{R}^{2}$ & 0.8840 & 0.9031 & 0.9428 & 0.8999 & 0.9051 & 0.8520 \\
\hline & \multirow{4}{*}{298} & $\mathrm{k}_{1}\left(\min ^{-1}\right)$ & 0.0404 & 0.0457 & 0.0520 & 0.0546 & 0.0492 & 0.0436 \\
\hline & & $\mathrm{q}_{\mathrm{e} \exp }(\mathrm{mg} / \mathrm{g})$ & 9.302 & 12.443 & 16.102 & 20.442 & 24.556 & 29.091 \\
\hline & & $\mathrm{q}_{\mathrm{e} \mathrm{cal}}(\mathrm{mg} / \mathrm{g})$ & 9.415 & 15.194 & 13.813 & 32.671 & 29.9670 & 32.773 \\
\hline & & $\mathrm{R}^{2}$ & 0.9123 & 0.9091 & 0.9536 & 0.8810 & 0.9029 & 0.9088 \\
\hline \multirow{8}{*}{ MB } & \multirow{4}{*}{308} & $\mathrm{k}_{1}\left(\min ^{-1}\right)$ & 0.0381 & 0.0475 & 0.0454 & 0.0524 & 0.0469 & 0.0488 \\
\hline & & $\mathrm{q}_{\mathrm{e} \exp }(\mathrm{mg} / \mathrm{g})$ & 9.893 & 13.441 & 17.557 & 21.314 & 26.075 & 30.249 \\
\hline & & $\mathrm{q}_{\mathrm{e} \mathrm{cal}}(\mathrm{mg} / \mathrm{g})$ & 9.511 & 16.675 & 17.003 & 28.281 & 41.846 & 40.923 \\
\hline & & $\mathrm{R}^{2}$ & 0.9423 & 0.8794 & 0.9374 & 0.9298 & 0.9128 & 0.8937 \\
\hline & \multirow{4}{*}{318} & $\mathrm{k}_{1}\left(\min ^{-1}\right)$ & 0.0570 & 0.0467 & 0.0476 & 0.0471 & 0.0538 & 0.0519 \\
\hline & & $\mathrm{q}_{\mathrm{e} \exp }(\mathrm{mg} / \mathrm{g})$ & 10.359 & 14.326 & 18.249 & 22.806 & 27.3075 & 31.862 \\
\hline & & $\mathrm{q}_{\mathrm{e} \mathrm{cal}}(\mathrm{mg} / \mathrm{g})$ & 16.589 & 19.265 & 19.129 & 27.777 & 5.656 & 58.644 \\
\hline & & $\mathrm{R}^{2}$ & 0.9112 & 0.9078 & 0.9086 & 0.9348 & 0.8719 & 0.8319 \\
\hline & Temp. & PSO kinetic & 30 & 40 & 50 & 60 & 70 & 80 \\
\hline & $(\mathrm{K})$ & coefficients & $(\mathrm{mg} / \mathrm{L})$ & $(\mathrm{mg} / \mathrm{L})$ & $(\mathrm{mg} / \mathrm{L})$ & $(\mathrm{mg} / \mathrm{L})$ & $(\mathrm{mg} / \mathrm{L})$ & $(\mathrm{mg} / \mathrm{L})$ \\
\hline & & $\mathrm{k}_{2}(\mathrm{~g} / \mathrm{mg} \cdot \min )$ & 0.0038 & 0.0037 & 0.0033 & 0.0026 & 0.0016 & 0.0011 \\
\hline & & $\mathrm{q}_{\mathrm{e} \exp }(\mathrm{mg} / \mathrm{g})$ & 8.362 & 11.757 & 15.311 & 19.812 & 23.158 & 27.000 \\
\hline & 298 & $\mathrm{q}_{\mathrm{ec} \text { cal }}(\mathrm{mg} / \mathrm{g})$ & 9.662 & 12.953 & 16.978 & 21.882 & 26.455 & 31.447 \\
\hline & & $\mathrm{R}^{2}$ & 0.9795 & 0.9912 & 0.9899 & 0.9910 & 0.9766 & 0.9796 \\
\hline \multirow{12}{*}{ NB } & \multirow{4}{*}{308} & $\mathrm{k}_{2}(\mathrm{~g} / \mathrm{mg} \cdot \min )$ & 0.0083 & 0.0048 & 0.0039 & 0.0026 & 0.0015 & 0.0012 \\
\hline & & $\mathrm{q}_{\mathrm{e} \exp }(\mathrm{mg} / \mathrm{g})$ & 8.594 & 11.840 & 15.996 & 20.472 & 24.446 & 28.614 \\
\hline & & $\mathrm{q}_{\mathrm{eccal}}(\mathrm{mg} / \mathrm{g})$ & 9.174 & 12.987 & 17.391 & 22.321 & 29.155 & 32.679 \\
\hline & & $\mathrm{R}^{2}$ & 0.9953 & 0.9908 & 0.9934 & 0.9925 & 0.9822 & 0.9766 \\
\hline & \multirow{4}{*}{318} & $\mathrm{k}_{2}(\mathrm{~g} / \mathrm{mg} \cdot \min )$ & 0.0096 & 0.0048 & 0.0051 & 0.0026 & 0.0014 & 0.0015 \\
\hline & & $\mathrm{q}_{\mathrm{e}} \exp (\mathrm{mg} / \mathrm{g})$ & 8.740 & 12.452 & 16.301 & 20.599 & 24.778 & 29.462 \\
\hline & & $\mathrm{q}_{\text {e cal }}(\mathrm{mg} / \mathrm{g})$ & 9.276 & 13.532 & 17.212 & 22.624 & 28.329 & 32.679 \\
\hline & & $\mathrm{R}^{2}$ & 0.9964 & 0.9910 & 0.9972 & 0.9906 & 0.9974 & 0.9937 \\
\hline & \multirow{4}{*}{298} & $\mathrm{k}_{2}(\mathrm{~g} / \mathrm{mg} \cdot \min )$ & 0.0107 & 0.0098 & 0.0096 & 0.0040 & 0.0038 & 0.0021 \\
\hline & & $\mathrm{q}_{\mathrm{e}} \exp (\mathrm{mg} / \mathrm{g})$ & 9.302 & 12.443 & 16.102 & 20.442 & 24.556 & 29.091 \\
\hline & & $\mathrm{q}_{\mathrm{ec} \text { cal }}(\mathrm{mg} / \mathrm{g})$ & 9.775 & 13.106 & 16.722 & 21.786 & 25.974 & 31.645 \\
\hline & & $\mathrm{R}^{2}$ & 0.9964 & 0.9972 & 0.9985 & 0.9959 & 0.9968 & 0.9914 \\
\hline \multirow{8}{*}{ MB } & \multirow{4}{*}{308} & $\mathrm{k}_{2}$ (g/mg.min) & 0.0115 & 0.0072 & 0.0066 & 0.0045 & 0.0027 & 0.0025 \\
\hline & & $\mathrm{q}_{\mathrm{e} \exp }(\mathrm{mg} / \mathrm{g})$ & 9.893 & 13.441 & 17.557 & 21.314 & 26.075 & 30.249 \\
\hline & & $\mathrm{q}_{\text {e cal }}(\mathrm{mg} / \mathrm{g})$ & 10.309 & 14.104 & 18.382 & 22.522 & 27.933 & 32.258 \\
\hline & & $\mathrm{R}^{2}$ & 0.9976 & 0.9963 & 0.9982 & 0.9966 & 0.9941 & 0.9947 \\
\hline & \multirow{4}{*}{318} & $\mathrm{k}_{2}(\mathrm{~g} / \mathrm{mg} \cdot \min )$ & 0.0106 & 0.0072 & 0.0062 & 0.0041 & 0.0023 & 0.0020 \\
\hline & & $\mathrm{q}_{\mathrm{e} \exp }(\mathrm{mg} / \mathrm{g})$ & 10.359 & 14.326 & 18.249 & 22.806 & 27.307 & 31.862 \\
\hline & & $\mathrm{q}_{\mathrm{ecal}}(\mathrm{mg} / \mathrm{g})$ & 10.834 & 15.083 & 18.975 & 24.038 & 28.326 & 33.014 \\
\hline & & $\mathrm{R}^{2}$ & 0.9966 & 0.9948 & 0.9984 & 0.9967 & 0.9966 & 0.9963 \\
\hline
\end{tabular}

Kinetic studies displayed that adsorption of AB25 process follows the PSO model and suggested that the step of ratelimiting could be the dye chemisorption. $\mathrm{R}^{2}$ coefficients are higher than 0.99 with experimental and evaluated qe values very close to each other. Kinetic constants are closer to both temperatures and concentrations, and qe values are increases with increasing concentration of AB25.

Thermodynamic studies demonstrate that this adsorption process is occurred endothermic. Thermodynamic parameters of AB25 adsorption on acid-thermal co-modified bentonite are higher than natural bentonite and the parameters which obtained with natural bentonite were found to be the lowest values. The highest absolute values of free energy of AB25 onto natural and acid-thermal co-modified bentonite changes from $4.0647 \mathrm{~kJ} / \mathrm{mol}$ to $8.5855 \mathrm{~kJ} / \mathrm{mol}$, respectively. The AB25 enthalpy values onto natural and acid-thermal co-modified bentonite changes from $5.483 \mathrm{~kJ} / \mathrm{mol}$ to $11.249 \mathrm{~kJ} / \mathrm{mol}$, and entropy values on natural and acid-thermal co-modified bentonite changes from $4.759 \mathrm{~J} / \mathrm{mol} . \mathrm{K}$ to $8.940 \mathrm{~J} / \mathrm{mol} . \mathrm{K}$, respectively. 
Adsorption amount was observed as maximum at acidic conditions but adsorption reduced slowly with the rise in $\mathrm{pH}$ values. $\mathrm{pHzPC}$ values of natural and modified bentonite were obtained 8.95 and 8.55, respectively. It was also found that acidthermal co-modified bentonite possesses higher adsorption capacity compared to natural bentonite. All of these results reveal that bentonite may be interesting an inexpensive material concerning other adsorbents used for dye removal.

\section{References}

[1] Yagub MT, Sen TK, Afroze S, Ang HM. "Dye and its removal from aqueous solution by adsorption: a review". Advances Colloid Interface Science, 209, 172-84, 2014.

[2] Kausar A, Iqbal M, Javed A, Aftab K, Nazli ZH, Bhatti HN, Nouren S. "Adsorption Using Clay and Modified Clay: A Review". Journal of Molecular Liquids, 256, 395-407, 2018.

[3] Yuhao C, Bing T, Liying B, Shaosong H, Ping L, Fenglian F, "Constructing a multi-layer adsorbent for controllably selective adsorption of various ionic dyes from aqueous solution by simply adjusting pH". Chemical Engineering Journal, 382, 1-13, 2020.

[4] Gupta V. K, Suhas. "Application of low-cost adsorbents for dye removal-a review". Journal of Environmental Management, 90, 2313-2342, 2009.

[5] Daneshvar E, Sohrabi MS, Kousha M, Bhatnagar A, Aliakbarian B, Converti A, Norrstro"me AC. "Shrimp shell as an efficient bioadsorbent for Acid Blue 25 dye removal from aqueous solution". Journal of the Taiwan Institute of Chemical Engineers, 45, 2926-2934, 2014.

[6] Huang Z, Li Y, Chen W, Shi J, Zhang N, Wang X, Li Z, Gao L, Zhang Y. "Modified bentonite adsorption of organic pollutants of dye wastewater". Materials Chemistry and Physics, 202, 266-276, 2017.

[7] Yanbo Z, Jian L, Yi Z, Yongdi L. "Recent advances for dyes removal using novel adsorbents: A review". Environmental Pollution, 252, 352-365, 2019.

[8] Líbia NFQ. Denise BF. Francisco R. Ieda MGS. Maria GF. Maguy J. "Functionalized bentonites for dye adsorption: Depollution and production of new pigments". Journal of Environmental Chemical Engineering, 7(5), 1-10, 2019.

[9] Zhao S, Gao W, Wu H, Deligeer W, Asuha S. "Direct acid activation of bentonite and its effects on the adsorption of methylene blue". Applied Clay Science, 126, 98-106, 2016.

[10] Abdelrahman MA, Shifa MRS, R J, Mona HG, Mustafa SN, Abdelbaki B, Samer A. "Adsorption of organic pollutants by natural and modified clays: A comprehensive review". Separation and Purification Technology, 228, 1-39, 2019.

[11] Benguella B, Yacouta-Nour A. "Adsorption of bezanyl red and nylomine green from aqueous solutions by natural and acid-activated bentonite". Desalination, 235(1-3), 276-292, 2009.

[12] Leodopoulos Ch, Doulia D, Gimouhopoulos K, Triantis T. M. "Single and simultaneous adsorption of methyl orange and humic acid onto bentonite". Applied Clay Science, 70, 84-90, 2012.

[13] Crini G. "Non-conventional low-cost adsorbents for dye removal: A review". Bioresource Technology, 97(9), 1061-1085, 2006.

[14] Tholiso N, Jabulani RG, Vhahangwele M, Arjun M. "An update on synthetic dyes adsorption onto clay based minerals: A state-of-art review". Journal of Environmental Management, 191, 35-57, 2017.
[15] Forgacs E, Cserhati T, Oros G. "Removal of synthetic dyes from wastewaters: a review". Environment International, 30, 953-971, 2004.

[16] Robinson T, McMullan G, Marchant R, Nigam P. "Remediation of dyes in textile effluent: a critical review on current treatment technologies with a proposed alternative". Bioresource Technology, 77, 247-255, 2001.

[17] Luo H, Huang X, Luo Y, Li Z, Li L, Gao C, Xiong J, Li W. "Adsorption behavior and mechanism of acidic blue 25 dye onto cucurbit[8]uril: A spectral and DFT study". Spectrochimia Acta A Molecular and Biomolecular Spectroscopy, 193, 125-132, 2018.

[18] Tovar-Gómeza R, Moreno-Virgen M.d.R, Moreno-Pérez J, Bonilla-Petriciolet A, Hernández-Montoya V, Durán-Valle CJ. "Analysis of synergistic and antagonistic adsorption of heavy metals and acid blue 25 on activated carbon from ternary systems". Chemical Engineering Research and Design, 93, 755-772, 2015.

[19] Thirumoorthy K, Krishna SK. "Removal of cationic and anionic dyes from aqueous phase by Ball clay - Manganese dioxide nanocomposites". Journal of Environmental Chemical Engineering, 8(1), 1-14, 2020.

[20] Auta M, Hameed BH. "Preparation of waste tea activated carbon using potassium acetate as an activating agent for adsorption of acid blue 25 dye". Chemical Engineering Journal, 171, 502-509, 2011.

[21] Ngah WSW, Ariff NFM, Hanafiah MAKM. "Preparation, characterization, and environmental application of crosslinked chitosan-coated bentonite for tartrazine adsorption from aqueous solutions". Water, Air, and Soil Pollution, 206(1-4), 225-236, 2010.

[22] Kul A, Koyuncu H. "Adsorption of $\mathrm{Pb}(\mathrm{II})$ ions from aqueous solution by native and activated bentonite: kinetic, equilibrium and thermodynamic study". Journal of Hazardous Materials, 179, 332-339, 2010.

[23] Elmoubarki R, Mahjoubi FZ, Tounsadi H, Moustadraf J, Abdennouri M, Zouhri A, El Albani A, Barka N. "Adsorption of textile dyes on raw and decanted moroccan clays: kinetics, equilibrium and thermodynamics". Water Resources and Industry, 9, 16-29, 2015.

[24] Salleh MAM, Mahmoud DK, AbdulKarim WAW, Idris A. "Cationic and anionic dye adsorption by agricultural solid wastes: a comprehensive review". Desalination, 280 (1-3), 1-13, 2011.

[25] Zhao XH, Zhen Z, Dan DW, Jue W, Yu RL. "Adsorption Kinetics and Thermodynamics of Acid Blue 25 and Methylene Blue Dye Solutions on Natural Sepiolite". Synthesis and Reactivity in Inorganic, Metal-Organic, and Nano-Metal Chemistry, 44(1), 140-147, 2014.

[26] Kul AR, Aldemir A, Elik H. "Adsorption of acid blue 25 on peach seed powder: isotherm, kinetic and thermodynamic studies". Environmental Research and Technology, 2(4), 233-242, 2019.

[27] Chen B, Hui CW, McKay G. "Film-pore diffusion modeling and contact time optimization for the adsorption of dyestuffs on pith". Chemical Engineering Journal, 84, 77-94, 2001.

[28] Hanafiah MAKM, Ngah WSW, Zolkafly Teong LC, AbdulMajid ZA. "Acid Blue 25 adsorption on base treated Shorea dasyphylla sawdust: kinetic, isotherm, thermodynamic and spectroscopic analysis". Journal of Environmental Sciences, 24(2), 261-268, 2012. 
[29] Ho YS, McKay G. "Sorption of dyes and copper ions onto biosorbents". Process Biochemistry, 38(7), 1047-1061, 2003.

[30] Fu Y, Viraraghavan T. "Fungal decolorization of dye wastewaters: a review". Bioresource Technology, 79(3), 251-262, 2001.

[31] Sadeghi S, Moghaddam AZ, Massinaei M. "Novel tunable composites based on bentonite and modified tragacanth gum for removal of acid dyes from aqueous solutions". RSC Advances, 5, 55731-55745, 2015.

[32] Phan TNT, Bacquet M, Morcellet M. "Synthesis and characterization of silica gels functionalized with monochlorotriazinyl $\beta$-cyclodextrin and their sorption capacities towards organic compounds". Journal of Inclusion Phenomena Macrocyclic Chemistry, 38(1), 345-359, 2000.
[33] Khadijah K, Wan SWN, Megat AKMH, Nur SAM, Siti NMK. "Acid Blue 25 Adsorption onto Phosphoric Acid Treated Rubber Leaf Powder". American Journal of Environmental Engineering, 5(3A), 19-25, 2015.

[34] Ferrero F. "Dye removal by low cost adsorbents: Hazelnut shells in comparison with wood sawdust". Journal of Hazardous Materials, 142, 144-152, 2007. 